ББК: 85.103(3)

УДК: 75.056

DOI: $10.18688 / \mathrm{aa} 2111-05-40$

\title{
A. Heiremans
}

\section{Representation of Proverbs in Flemish Marginal Art of the $13^{\text {th }}-15^{\text {th }}$ Centuries}

It seems like the margins of a medieval manuscript, being liminal spaces themselves, were home to everything that did not fit, that was pushed out of the official belief system, but that was in fact deeply cherished by the society - folklore. Margins provided a safe space for the transmission of folk narratives and proverbs that have inspired some of the most twisted, whimsical images found in Flemish marginal art. However, before we proceed, a few words need to be said about medieval folklore and popular belief, which served as a major source of influence on medieval marginalia.

The world of medieval folklore has long been considered unattainable or did not spark much interest among historians. The common people, as Aron Gurevich rightly observed, were the "great mute", "the absent one", unlike the "high-brow" theologians, phisosophers and other literati $[11, \mathrm{p} . \mathrm{XV}]$. "Too often, original ideas or beliefs have been considered by definition to be a product of the upper classes, and their diffusion among the subordinate classes a mechanical fact of little or no interest" [10, p.XIX], - writes Carlo Ginzburg. This aristocratic view of medieval popular culture has firmly established in the canon of scholarship; the common folk was thought to have been unable to produce ideas, but rather receive those imposed by the dominant class. At best, the "unofficial" culture of the Middle Ages would be referred to as "naive" or "primitive" for its superstitious beliefs and orientation "towards the fabulous and the fantastic" [11, p.XV]; likewise, the values and practices of the subordinate classes were often considered as remnants of ancient paganism.

This opposition between the official and popular belief, the high and the low cultures has long dominated historical scholarship, until Jacques Le Goff has suggested that the relationship between the culture of the "learned" and the "folkloric culture" was in fact much more diverse. Folklore, according to Le Goff, was refused and suppressed by the church, but also - to a certain extent adapted to the needs of official ideology. Le Goff also notes that there was a "real cultural gap $\langle\ldots\rangle$ between the fundamental ambiguity and equivocation of folklore (belief in forces which were both good and bad at the same time and, in general, a basic ambivalence in the cultural apparatus) and the "rationalism" of ecclesiastical culture" [15, pp.157-158]. However, folklore proved to be too vivacious to be eliminated and was thus partially absorbed by the dominant culture. But folkloric elements were accepted not only out of necessity; as Le Goff further explains, it was "encouraged by certain mental structures common to both cultures, in particular the confusion between terrestrial and supernatural, material and spiritual spheres (e.g., attitudes toward miracles, cults of relics, use of phylacteries, etc.)" [15, 
p. 156-157]. Mikhail Bakhtin stresses that in the Middle Ages, folklore and popular culture existed in confrontation with the official order and used every opportunity to break free from the system [3, p.71]. Michael Camille, on the other hand, suggests that popular culture was "a carefully controlled valve for letting off steam" [5, p. 143]; it was, however, integral to elite culture, both confronting and emphasizing its boundaries. He defines margins of a manuscript as an officially sanctioned space for play, parody and criticism; he also reminds that marginal imagery was made for aristocrats who could afford a purchase as expensive as a book, therefore it is important to remember that the view of folk life offered by the margins is often "screened through the lens of aristocratic perception" [5, p. 120].

But in order to discern these folkloric elements and look into the world of medieval popular culture we are inevitably faced with the problem of documentation, as folklore is predominantly oral; we, in turn, can only rely on sources that are written and are therefore almost always indirect. However, there are sources that do offer an insight into folklore and popular culture of the Middle Ages more than others. Among these sources are fables and the avidly read beast epics and romances, such as the celebrated Reynard the Fox literary cycle and the $12^{\text {th }}$-century "Ysengrimus", most likely written by a Flemish poet; fabliaux - short comic tales initially written and told by jongleurs in Northeast France between the $12^{\text {th }}$ and the $15^{\text {th }}$ centuries; Latin and vernacular French and Flemish proverbs preserved in a number a manuscripts ${ }^{1}$. Among other, perhaps less apparent sources, are exempla - moral anecdotes used by preachers in order to emphasize moral conclusions or demonstrate a point of doctrine. However, as time passed, "these collections began to emphasize stories intended to amuse $\langle\ldots$. . Hence, many examples in later collections resemble jokes or fabliaux, illustrating the sexual lapses of monks or priests and their parishioners. However, traditional narratives remain an integral part of folk preaching", writes Bill Ellis [19, p. 84]. It should also be noted that the scope of exempla would often include traditional folk narratives (such as fables), adapted in order to illustrate the doctrine, which makes it a valuable source of medieval folklore. All of these sources, along with many others, proved to have close ties with marginal imagery in Flemish manuscripts. It is, however, important to note that it is often hard to identify the initial source of the motif, as many of the aforementioned folkloric sources could refer to one another: a fabliau could be based on or allude to a proverb; a proverb could originate from a fable and vice versa.

In this article, I will address some of the proverbial motifs visualized in the margins of Flemish illuminated manuscripts produced in the late Middle Ages, as proverbs seem to be one of the favorite sources of inspiration for the artists who created those marginal images.

It is known, the inhabitants of the marginal realm are clearly unhappy with the natural order. Animals turn into humans and vice versa, prey chases hunters - it is the "topsy-turvy world", where reality is reversed, being consistently out of order. Here, women would fight with men to claim power. A common image found in the margins and on cathedral misericords shows a man and a woman (husband and wife, most likely), pulling in opposite directions a pair of trousers, sometimes holding a weapon in their free hands. Such image is found in the Franco-Flemish manuscript of the "Vows of the Peacock" ("Les Voeux du Paon'), one of the many

1 A collection of Middle Dutch proverbs has been translated by Pieter Harrebomée (1990) [12]; a great source for Middle French proverbs and sayings is an edition by Joseph Morawski (1925) [20]. 
additions to the story of Alexander the Great. In the image, we see a woman who has already captured the trousers and is now fending off her husband who is about to hit her (Ill. 115).

The image most likely alludes to the Flemish expression "de broek dragen" ("porter les chausses", "porter les culottes" in French) [22, p. 646], which means "to wear the breeches / to wear the trousers" and was often referred to a person's status as master in the house. A woman who would wear the trousers, who would take on male attributes, means that she had usurped the powers and privileges of her husband. The theme also underlines the humiliation of the weak and powerless husband who cannot take control over his wife.

The "battle for the breeches" motif is closely related to two $13^{\text {th }}$-century fabliaux, the "Fabliaux d'Estourmi" and the "Fabliau de Sire Hain et de Dame Anieuse"; central to all of these is a competition between wife and husband for the man's breeches, which will verify mastery of the household.

The theme is often confused with a similar one: the battle for the breeches between some women - a motif that refers to the proverb "The winner gets the man" or "Whoever wins the breeches gets the man" [13, fig. 159]. It is, however, important to notice that in this case, women are not fighting for the power and authority wielded by the man. Instead, it is more of an "erotic male fantasy, in which the women vie for the sexual favors of one man" [9, p. 221]. It has been suggested that this motif alludes to an excerpt from Isaiah, who speaks of the day when "seven shall take hold of one man, saying: We will eat our own bread,

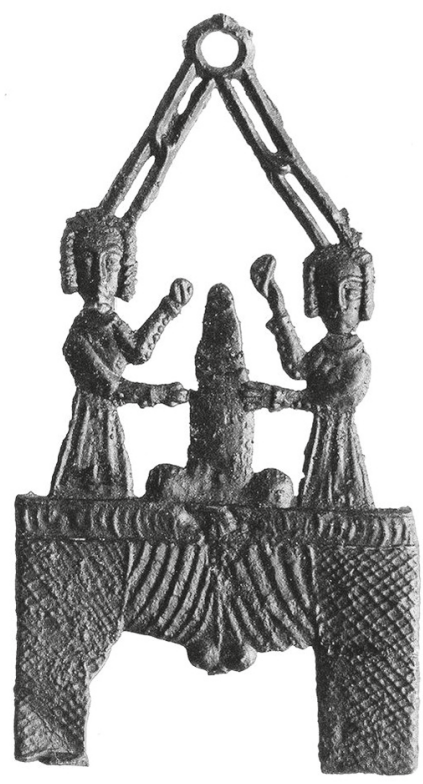

Fig. 1. Phallus emerging from trousers and stroked by two women, 1400-1450, $63 \times 33 \mathrm{~mm}$, found in Bruges, Van Beuningen family collection, Langbroek (c) Cothen, Stichting Religieuze en Profane Insignes and wear our own apparel, only let us be called by thy name, to take away our reproach" (Isaiah, 4:1). Isaiah thus alludes to the shortage of men after war, but, in the $15^{\text {th }}$ century, this passage inspired many humorous prints and even a few paintings.

Here, the breeches become a symbol for male potency and it is clear that women crave not the breeches themselves, but their very contents. This point is illustrated by a $15^{\text {th }}$ century lead badge found in Bruges, showing a pair of breeches from which a large phallus emerges, with two women on either side of it (Fig. 1).

The lower stratum of the body is often emphasized in Flemish marginal imagery. A common inhabitant of the marginal realm is a nude, or a half-nude man pointing to his buttocks or plugging his arse with a finger (Figs. 2, 3), which might allude to the saying "Plug your arse and you can't shit" ("A resoun pert le chïer qe soun cul estope") [20].

The nude pointing to his buttocks is often pictured facing someone else, as if they were engaged in some argument, and the naked man thus seems to be literally exemplifying the dirty talk, inviting to kiss his arse. This could also be the gesture of "mooning", that is, exposing the buttocks at someone, which itself was a sign of defiance or insult. At this point it is essential to clarify that the body image is closely 


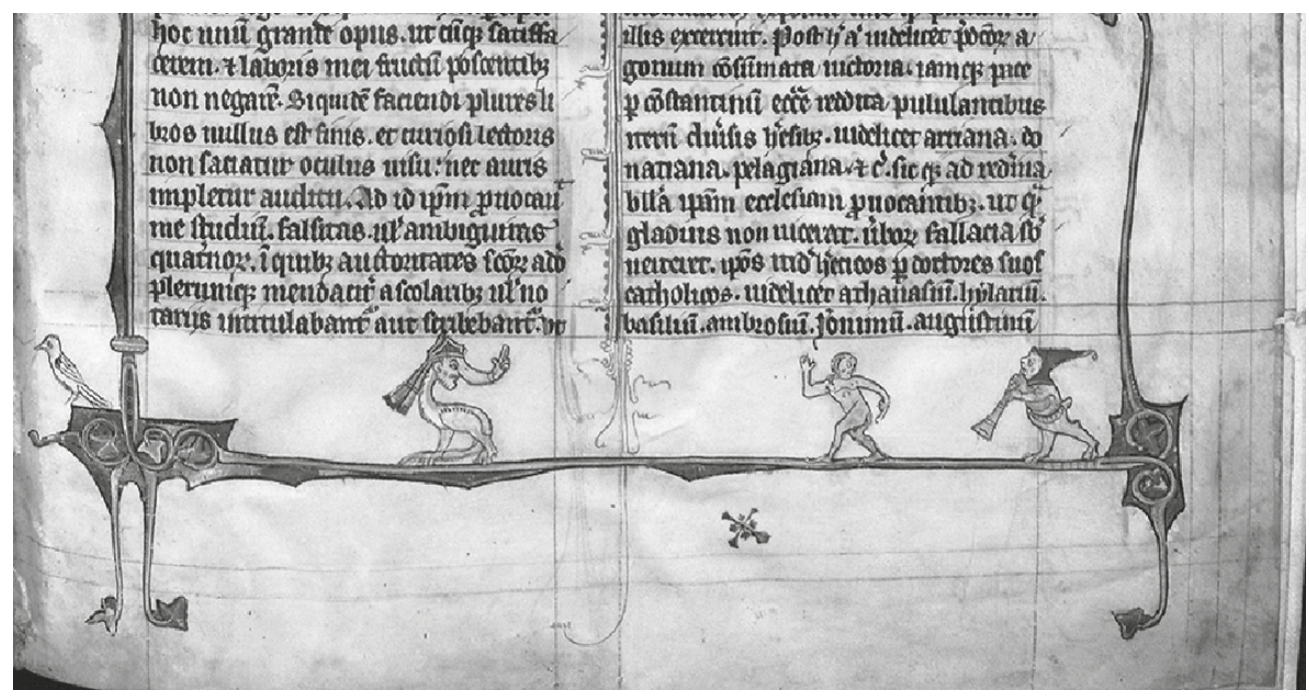

Fig. 2. Speculum Doctrinale (Bruges, Openbare Bibliotheek, MS 251), fol. 1r @ Openbare Bibloitheek

related to that of the universe, where "downward" is earth and "upward" is heaven, suggests Bakhtin. Therefore, the lower body is often associated with the earth, "an element that devours, swallows up (the grave, the womb) and at the same time an element of birth, of renascence" [3, p. 21], and bears the same symbolism of regeneration and rebirth.

The image of the lower body (the fornicating, the defecating part of the body), as well as much of the obscene language, focused mainly on the lower stratum of the body, is ambivalent: while being humiliating and mortifying, they also bear the sense of renewal and regeneration. The scatological imagery, common in Flemish marginal art, should be viewed in the same manner: "in the images of urine and excrement is preserved the essential link with birth, fertility, renewal, welfare", writes Bakhtin [3, p.21].

The margins of Flemish manuscripts are flooded with scatological imagery, often based on the same sentiment, same arse-generated humour, as numerous proverbs of the time that circulated in France and Flanders:

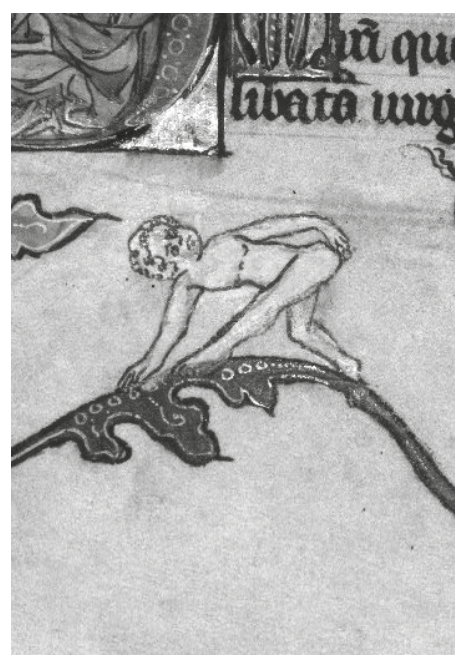

Fig. 3. Psalter-Hours (Baltimore, Walters Art Museum, MS W. 82), fol. 179v (C) Walters Art Museum

- He shits on the whole world

(Hij beschijt de geheele wereld) [6, p. 476]

- It only takes a little shit to soil big breeches (Petite merde conchie grans braies) [17, p. 37] 
- Stroke the donkey, and he'll pay you off with a fart / Sing to the donkey and he'll fart for you

(Krauw den ezel zijn staart, hij loont u met een scheet / Chantez à l'âne, il vous fera des petz) [12, p. CLXVI; 14, p. 485]

- He makes a thunder out of a fart (Hij maakt van een scheet een donderslag) [18, p.410]

- It's as surely as a fart in the net (Het is zo zeker als een scheet in een netje) [18, p.410]

- It's as true as the fact that an arse can sing (Il est vrai tout ainsi comme le cul chante) $)^{2}$

It seems like the first expression became best known through Bruegel's painting "Netherlandish proverbs", where a figure's rear is shown sticking out of the window and defecating on the globe. A very similar marginal image appears, however, in the $15^{\text {th }}$-century R\&K Hours, MS 158. The sense of the proverb shows man's satirical defiance towards the world. In this case, the renewing power of this scatological laughter is aimed at the world itself and thus bears a very peculiar message.

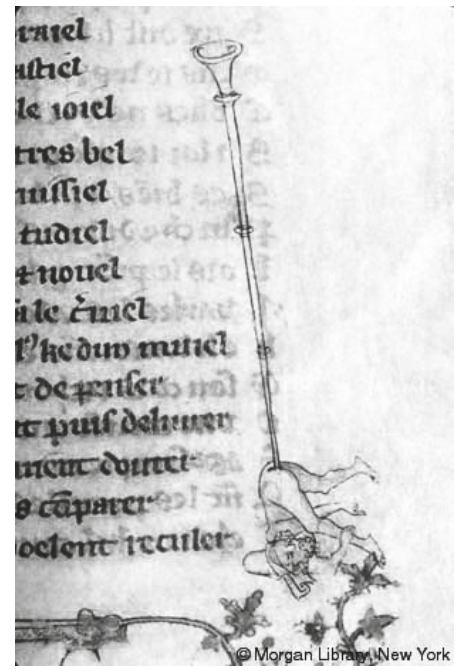

Fig. 4. Les Voeux du Paon (New York, Morgan Library, MS G. 24), fol.1r (c) Morgan Library

Many marginal images, directly or indirectly refer to the last saying, celebrating the musical gift of the arse. The musical butt is frequently encountered in the margins of Flemish manuscripts, and a bagpipe or trumpet appears to be its favourite instrument. "The Vows of the Peacock" manuscript, again, offers a great number of such images. On fol. 1 we come across a nude playing a shawm (type of a straight trumpet) with his anus (Fig. 4). Another example is found on fol. 82r, where nude buttocks, detached from the body, play bagpipe in the same manner.

This kind of imagery is very common and draws a broader analogy between musical instruments and the human body. Hilary of Poitiers compares Christ's body to a psaltery; Gregory of Nyssa believes that the human tongue is similar to the plectrum: we extract words from the mouth just the way our fingers pluck the strings. "The human body is an orchestra in microcosm: the throat, like a pipe, represents the wind instrument; the chest, like a harp, represents the stringed instrument; and the pulse a percussion instrument. 'Vox' (voice) refers to a single note of an instrument as well as to human sound. Predecessors of the keyboard, the sliders on the medieval organ were called 'linguae' (tongues)", writes Valerie Allen [2, p.29]. That way the lower stratum of the body acquires its musical functions and farting is thus often compared to singing or whistling, but more often - to "trumping". Jokes based on this analogy are very

2 As cited in: [16, p. 110]. 
common in the Middle Ages; the well-known example comes from the "Reynard the Fox" literary cycle, where the arse is referred to as "corneeur", that is, "trumpeter".

This imagery is, again, based on the reversal of the upper and lower body. In the margins, the body is fluid, unfinished; it is turned inside out and upside down. The same concept of the body is reflected in many folk tales, proverbs, and curses that are often based on the principle of degradation and inversion. But, not only does the body get affected by this degrading laughter, the whole marginal world seems to play by its rules.

In this topsy-turvy realm animals would often switch roles with humans. Animal musicians, that is, animals playing musical instruments the way humans do, were a common phenomenon of medieval 'droleria'. Ass, the clumsiest animal, according to many proverbs and folk stories, often appears playing the lyre or any other instrument. In the "Les Vows of the Peacock" manuscript, we find a marginal image of an ass playing a gittern (Ill. 116). The image could possibly allude to the Greek proverb "an ass listening to the lyre" (or "like an ass listening to the lyre") which was well-known to the Romans; it was then used by Boethius in his "Consolation of Philosophy" [1]. It soon became a household word to the Middle Ages down to the time of Erasmus. As we can see, the original meaning of the expression did not denote asses' failure at playing the lyre, but rather stressed his poor listening skills, the blank state of mind; however, the initial sense of the proverb must have been "considerably diluted in the art of the late Middle Ages" [8, p. 38]. In this new sense, the proverb was used by the Antwerp schoolteacher and poet Anna Bijns some time before 1540: "Hoe souden ezels pooten / op herpe spelen" ("How should the ass play the harps with his hooves? $)^{3}$. However, marginal images found in a number of manuscripts attest to the fact that the proverb was known in Flanders long before that.

But not only do marginal animals become musicians, they might as well turn into clerics. Most commonly, a fox would appear dressed as a bishop or as a mendicant friar, sometimes preaching to a flock of birds (typically geese or roosters). In the margins of the "Les Voeux du Paon" manuscript, we encounter a fox (that does, however, resemble a wolf) wearing a bishop's robe and a miter, with a crozier in its paw. In the same manuscript, we find an image of a fox dressed as a monk, preaching to some hybrid with multiple heads. $15^{\text {th }}$-century manuscripts offer a wider range of images conforming to the general iconography of a fox-cleric. Thus, in the manuscript of Froissart's "Chronicles", we come across a fox disguised as a pilgrim preaching to a hen ready to gobble it up (Fig. 5); a very similar image is found in the "Hours of Mary of Burgundy" manuscript. Another image from the same "Hours of Burgundy" manuscript shows the fox pilgrim with the captured birds peeping out of his hood (Fig. 6). The motif is most certainly drawn from the "Reynard the Fox" cycle, where, according to the Middle Dutch version, Reynard is accused of having murdered the children of the cock Cantecleer, tricked into believing that the fox had become a monk and would not do any harm [4, pp. 64-67].

However, apart from the famous beast epic, there was also a proverb well known during the Middle Ages: "When the fox preaches, beware your geese" [23, p. 166] or "When the fox starts preaching, watch your chicken"4, which might have inspired some of the earlier images that do not correspond to the traditional iconography of Reynard the Fox preaching to the cock.

As cited in: [8, p.37].

As cited in: [16, p. 107]. 


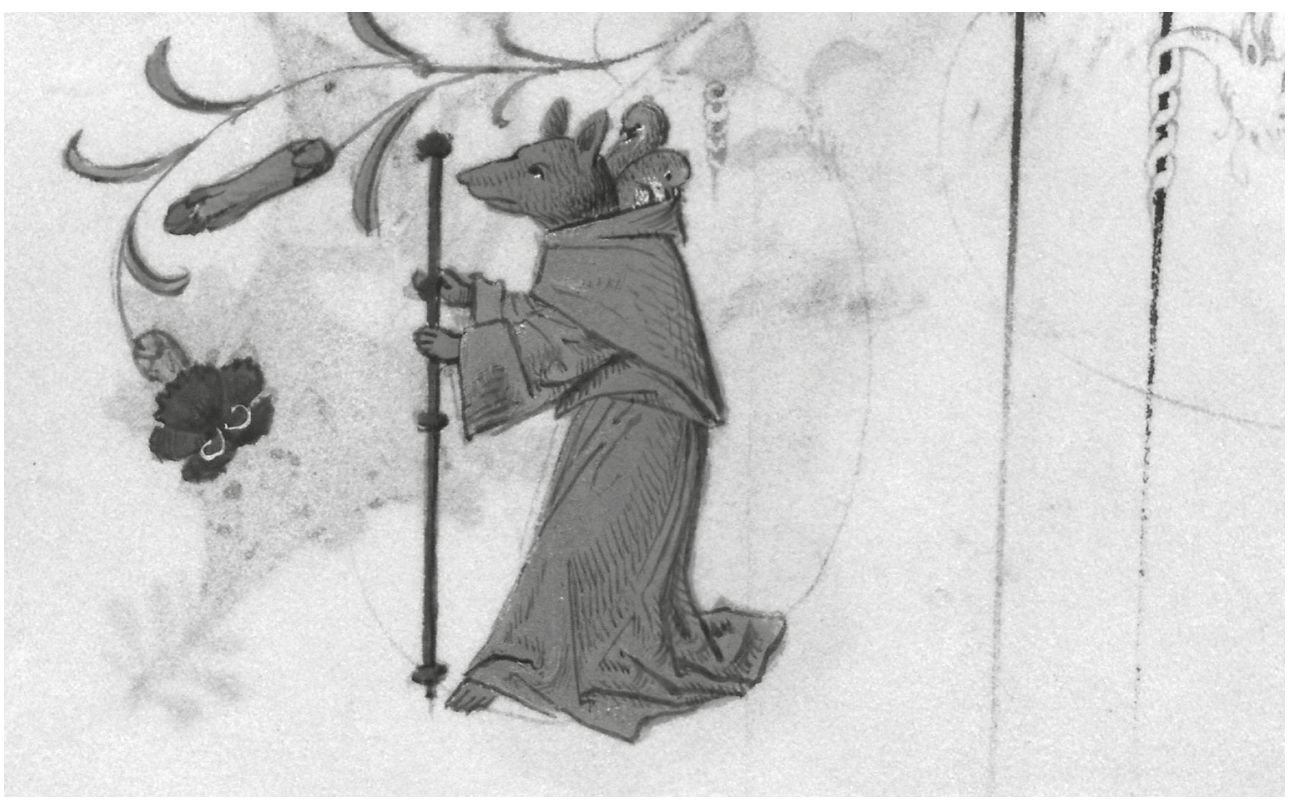

Fig. 5. Chroniques de Jean Froissart (Paris, Bibliothèque Nationale de France, MS fr. 2646), fol. 6r (C) Bibliothèque Nationale de France

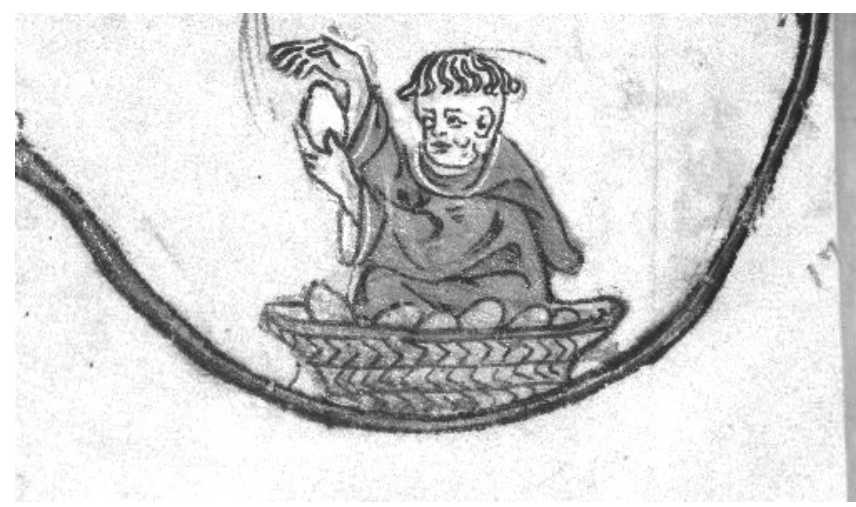

Fig. 6. Hours of Mary of Burgundy (Vienna, Österreichische Nationalbibliothek, Cod. 1857), fol. 59v (C) Österreichische Nationalbibliothek

Clearly, animals disguised as preachers most likely represent "ruler's misuse of power and corruption of justice, or demonstrate the hypocrisy of the heretic" [7, p. 13]. But animal analogies used to describe corrupt preachers were not invented in the Middle Ages, and Reynard the Fox was certainly not the first one to expose the preacher's vices. It is possible that the inspiration for these images was found in St. Matthew's Gospel: "Beware of false prophets which come 
to you in sheep's clothing, but inwardly they are ravening wolves" (Matthew 7:15). It should also be mentioned that animal analogies were used to describe the good preachers as well: those were often compared to peacocks, whose "golden plumes signify the sacred doctrine" [7, p. 12] and whose "terrible voice signifies the constancy of the preacher and his sharpness in reproaching vice" [7, p. 12]. A good preacher would also be compared to the dog, barking out against vices and biting sinners [7, p. 12].

However, the good preachers do not seem to be welcome in the marginal spaces, as they are not considered "marginal" in terms of their behavior or social status and thus do not deserve to be ridiculed. The margins, as we have seen, are mostly concerned with human imperfection and everything that happens to be beyond natural or desirable order (and therefore becomes the object of mockery and parody), beyond the established hierarchy, beyond the official belief system.

But, there is no doubt that the animal that epitomizes

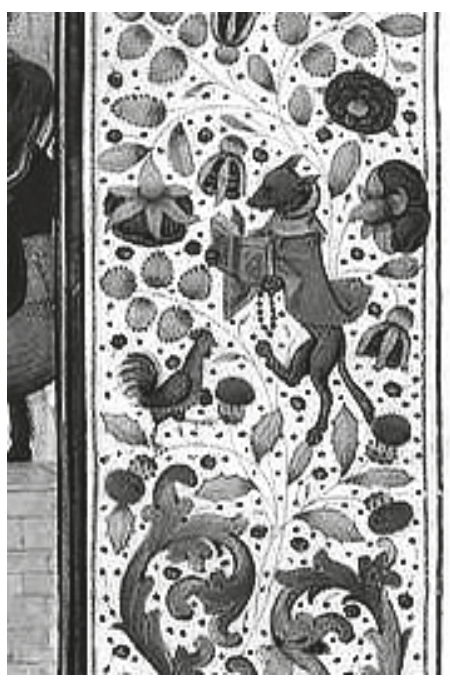

Fig. 7. Psalter-Hours (Baltimore, Walters Art Museum, MS W. 82), fol. 179v (C)

Walters Art Museum the upside-down world by its very nature is the ape. Apes mirror the human world in a humorous, often derisive way, taking on all kinds of appearances: there are apes appearing as clergy, knights, hunters, musicians and physicians. Most of the ape images do not refer to any proverb, being just a result of the illuminator's fantasy. There is, however, one image that deserves our attention. In "The Vows of the Peacock" we find an image of an ape and a demon who share a meal - an image that likely refers to the proverb "He who sups with the Devil needs a long spoon" [16, p. 103], which means that one should be cautious when dealing with wicked people.

As we have seen, in the upside-down realm of marginal imagery, animals often behave in a human way; hence, the humans are expected to take on animal qualities and act in a nonhuman manner. One of the most recurring images in the margins of Flemish manuscripts is that of a man sitting on the nest full of eggs and holding one up to the sun as though candling it or checking its readiness to hatch (Ill. 117, Fig. 7).

According to Lillian Randall, the egg-hatching motif designated political slander against the Englishmen. In the short period between 1294 and 1296, that is, at the time when most of the aforementioned manuscripts were produced, the count of Flanders made and broke alliances with the English king, Edward I. These disputes gave rise to criticism in French and Flemish literature, where the Englishmen would often be called "long-tails" and from then on, it became a common anti-English insult. And, since in medieval French the words "coué" (tailed) and "couve" (hatched) were pronounced (and sometimes spelled) alike, the tailed English came to be the English who were foolish enough to hatch eggs: "At first probably used interchangeably with "coué", the concept of hatching soon developed into an independent term of abuse. The expression, which lent itself readily to numerous interpretations, introduced welcome variations to the classic theme of Anglophobia. It offered further proof of English stupidity, for 
only a fool would sit on eggs to hatch them" [21, p.35]. Over time, however, the motif has lost its original meaning and became "the epitomization of Folly" [21, p. 35]. In a series of Flemish prints depicting common contemporary proverbs and expressions, the image of a man wearing a fool's costume and hatching eggs was labelled "Hier is een narr op eijer geset", "Hier sit de sot op eyeren", or "Hier broet de sot de eyeren" [21, p. 29], that is, "Here is a fool sitting on the eggs" or "Here is a fool hatching the eggs".

But, there was another Flemish proverb, which Randall doesn't mention in her study, but which most certainly refers to the motif: "He shits eggs without shells" ("Hij schijt eieren zonder schalen") [13, p. 57]. Either way, the theme further develops into the "Folly hatching her brood" [21, p. 29], which might be explained by the fact that the word "fool" ("narr", "sot", but also "door") was often used interchangeably with "yolk" ("dooier").

So, as we can see, visualized proverbs constitute a great part of Flemish marginal imagery. Folklore seems to be the primary source (or at least one of the primary sources) of inspiration for the illuminators who decorated the borders of Flemish manuscripts. Looking at marginal imagery from the perspective of folklore and popular culture as a whole offers us a new take on the nature of border decoration in general, suggesting that there was a very natural kinship between folklore (both folk narratives and customs) and marginal art.

\section{References}

1. Adolf H. The Ass and the Harp. Speculum, 1950, vol. 25, no. 1, pp. 49-57.

2. Allen V. On Farting: Language and Laughter in the Middle Ages. New York, Palgrave Macmillan Publ., 2007. $239 \mathrm{p}$.

3. Bakhtin M. Rabelais and His World. Bloomington, Indiana University Press Publ., 1984. 484 p.

4. Bouwman A.; Besamusca B. (eds.); Summerfield T. (transl.). Of Reynaert the Fox. Text and Facing Translation of the Middle Dutch Beast Epic "Van den vos Reynaerde". Amsterdam, Amsterdam University Press Publ., 2009. $368 \mathrm{p}$.

5. Camille M. Image on the Edge: The Margins of Medieval Art. London, Reaktion Books, 2013. 176 p.

6. Classen A. Laughter as the Utimate Epistemological Vehicle in the Hands of Till Eulenspiegel. Neophilologus, 2008, vol. 92, no. 3, pp. 471-489.

7. Cohen S. Animals as Disguised Symbols in Renaissance Art. Leiden, Brill Publ., 2008. 316 p.

8. Gibson W.S. Asinus ad lyram: From Boethius to Breughel and beyond. Simiolus: Netherlands Quarterly for the History of Art, 2007-2008, vol. 33, no. 1/2, pp. 33-42.

9. Gibson W. S. A Sacred Text Profaned. Seven Women Fight for the Breeches. Block E. C. (ed.). Profane Images in Marginal Arts of the Middle Ages. Turnhout, Brepols Publ., 2009, pp. 221-237.

10. Ginzburg C. The Cheese and the Worms: The Cosmos of Sixteenth-Century Miller. Baltimore, The John Hopkins University Press Publ., 1980. 177 p.

11. Gurevich A. Medieval Popular Culture: Problems of Belief and Perception. Cambridge, New York, Cambridge University Press Publ., 1988. XX plus 275 p.

12. Harrebommé P. J. Spreekwoorden der Nederlansche taal, vol. 2. Hoevelaken, Verba B. V.Publ., 1990. 463 p. (in Dutch).

13. Kraus D.; Kraus H. The Hidden World of Misericords. London, Michael Joseph Publ., 1976. 191 p.

14. Leboux de la Mésangère P.-A. Dictionnaire des proverbes français. Paris, 1823. 591 p. (in French).

15. Le Goff J. Time, Work and Culture in the Middle Ages. Chicago, London, The University of Chicago Press Publ., 1980. 400 p.

16. Leo D. Images, Texts, and Marginalia in a "Vows of the peacock" Manuscript (New York, Pierpont Morgan Library, MS G24). Leiden, Brill Publ., 2013. 448 p.

17. Lorcin M.-T.; Schulze-Busacker E. Les recueils de proverbes français, 1160-1640: sagesse des nations et langue de bois. Paris, Honoré Champion Publ., 2011. 156 p. (in French). 
18. Mandos H.; Mandos — van de Pol M. De Brabantse spreekwoorden: uitdrukkingen in Brabant gebruikt en opgetekend. Liempde; Zaltbommel, Kempen Publ., 2003. 680 p. (in Dutch).

19. McCormick C. T.; Kennedy White K. (eds.). Folklore: An Encyclopedia of Beliefs, Customs, Tales, Music and Art, vol. 1. Santa Barbara, Denver, Oxford, ABC-CLIO Publ., 2011. 1287 p.

20. Morawski J. (ed.). Proverbes français antérieurs au XVe siècle. Paris, Honoré Champion Publ., 1925. 146 p. Available at: http://txm.ish-lyon.cnrs.fr/bfm/pdf/prov.pdf. (accessed 5 May 2020) (in French).

21. Randall L. A Mediaeval Slander. The Art Bulletin, 1960, vol. 42, no. 1, pp. 25-38.

22. Stoett F. A. Nederlandsche spreekwoorden, spreekwijzen, uitdrukkingen en gezegden. Zutphen, W. J. Thieme Publ., 1901. 804 p.(in Dutch).

23. Varty K. Christine's Guided Tour of the "Salle merveilleuse". Campbell J.; Margolis N. (eds.). Christine de Pizan 2000. Studies on Christine de Pizan in Honour of Angus J. Kennedy. Amsterdam, Rodopi Publ., 1994. pp. 163-176.

Title. Representation of Proverbs in Flemish Marginal Art of the $13^{\text {th }}-15^{\text {th }}$ Centuries

Author. Heiremans, Alina - Ph. D. student. Catholic University of Leuven, 3000 Leuven, Oude Markt, 13, Belgium. alinaheiremans@gmail.com ORCID: 0000-0002-3931-8660

Abstract. In the article, the author attempts to draw a link between marginal imagery found in Flemish illuminated manuscripts and medieval Flemish and French proverbs, proving that marginalia and folklore have many points of intersection. A common motif, found in the margins of Flemish manuscripts, shows a man and a woman (or two women) fighting for the britches and most likely refers to the proverb "Whoever wins the britches gets the man". The proverb is also related to two $13^{\text {th }}$-century fabliaux, where a competition between wife and husband for the man's britches is emphasized. Many of the marginal images are associated with nudity and, more specifically, with the lower stratum of the body. A common inhabitant of the marginal realm is a nude, or a half-nude man pointing to his buttocks or often plugging his arse with a finger, which might allude to common sayings that circulated in France and Flanders at the time. Some images would refer to the saying "It's as true as the fact that an arse can sing" ("Il est vrai tout ainsi comme le cul chante") and others, celebrating the "musical gift" of the arse. The musical butt is frequently encountered in the margins of Flemish manuscripts, and a bagpipe or trumpet appears to be its favourite instrument, as farting would often be compared to trumping in many sayings. A Flemish expression "He shits on the whole world" ("Hij beschijt de geheele wereld"), which became best known through Brueghel's painting "Netherlandish proverbs", is reflected in a marginal image of a man, defecating on a globe, is found in the $15^{\text {th }}$-century book of hours of Roland de Wedergate (MS 158). A Flemish saying "He shits eggs without shells" ("Hij schijt eieren zonder schalen") might have inspired the recurring image of a man, sitting on the nest full of eggs.

Keywords: Middle Ages, marginalia, folklore, proverbs, Flanders

Название статьи. Изображение поговорок в маргиналиях фламандских рукописей XIII-XV веков

Сведения об авторе. Хейреманс, Алина Михаэловна - аспирант. Лёвенский католический университет. 3000 Лёвен, Уде Маркт, 13, Бельгия. h.aline@yandex.ru ORCID:0000-0002-3931-8660

Аннотация. В исследовании проводится параллель между маргинальными изображениями во фламандских иллюминированных рукописях XIII-XIV вв. и средневековыми фламандскими и французскими поговорками. Маргинальное искусство (изображения на полях средневековых рукописей, мизерикордиях или значках) было тесно связано с народной культурой и использовало фольклор в качестве основного, на взгляд автора, источника вдохновения. В статье проводится анализ изображений, построенных на известных в эпоху позднего Средневековья пословицах и поговорках, а также идентифицируется ряд мотивов, характерных для фламандского маргинального искусства. Среди рассматриваемых мотивов многие отсылают к телесному низу и имеют соответствующие аналоги в ругательствах и шутках; другие маргиналии запечатлевают животных, играющих на музыкальных инструментах (один из наиболее излюбленных мотивов - осел, играющий на лире - имеет в качестве источника античную пословицу, известную и в эпоху Средневековья) или прикидывающихся священнослужителями, как, например, лис-паломник, проповедующий перед петухом (мотив, заимствованный из животного эпоса о лисе Ренаре, но также отсылающий к известной средневековой поговорке); наконец, бесчисленное множество средневековых фламандских «дролери» отведено осмеянию человеческой глупости - распространенным мотивом, также имеющим тесную связь с устной культурой, является изображение человека, высиживающего яйца.

Ключевые слова: Средние века, маргиналии, фольклор, поговорки, Фландрия 


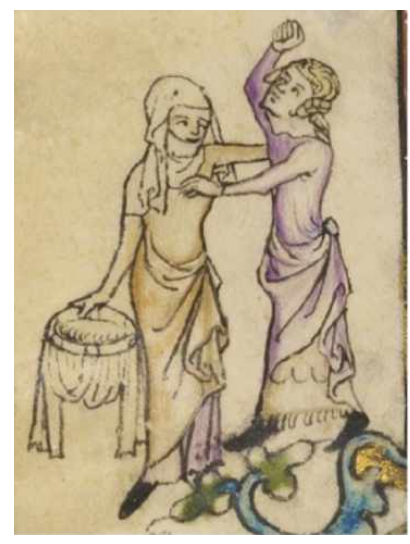

Ill. 115. Les Voeux du Paon (New York, Morgan Library, MS G. 24), fol. 6v (C) Morgan Library
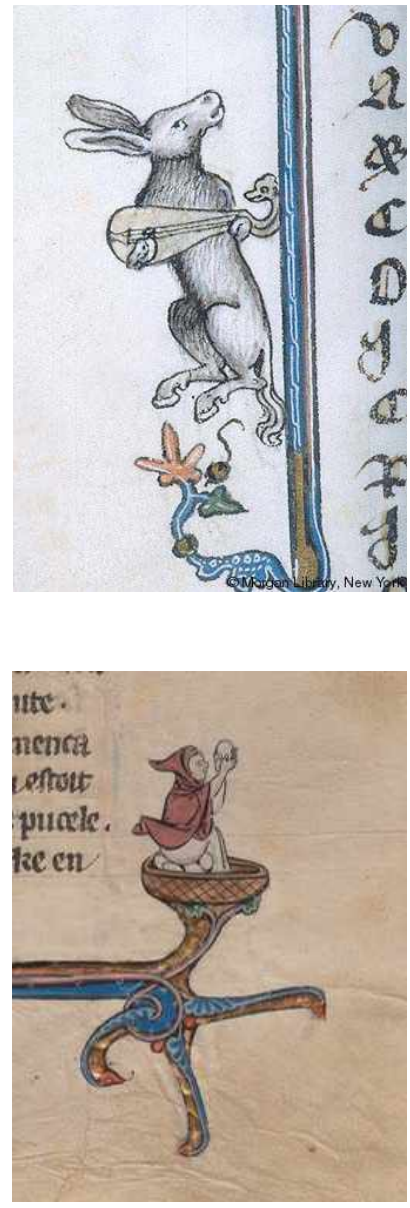

Ill. 116. Les Voeux du Paon (New York, Morgan Library, MS G. 24), fol. 48v (c) Morgan Library
Ill. 117. Arthurian Romance (New Haven, Beinecke Rare Book Library, MS 229), fol. 31r @ B Beinecke Rare Book Library 